\title{
Acetylation of $\alpha$-Tubulin in Cultured Neurons and the Induction of $\alpha$-Tubulin Acetylation in PC12 Cells by Treatment with Nerve Growth Factor
}

\author{
Mark M. Black and Patricia Keyser \\ Department of Anatomy, Temple University School of Medicine, Philadelphia, Pennsylvania 19140
}

$\alpha$-Tubulin of cultured neurons undergoes a posttranslational modification that lowers its p/ (Black and Kurdyla, 1983a). We show here that this modification is due to acetylation. Incubation of cultures with ${ }^{3} \mathrm{H}$-acetate results in the prominent labeling of a protein that comigrates with $\alpha$-tubulin in 1-dimensional SDS gels, and in 2-dimensional isoelectric focusing $\times$ SDS gels, it comigrates with the more acidic $\alpha$-tubulin forms. The labeled material can be immunoprecipitated by monoclonal antibodies to $\alpha$-tubulin but not by antibodies to $\beta$-tubulin. The reaction occurs to equal extent in the presence or absence of $0.1 \mathrm{~mm}$ cycloheximide or unlabeled amino acids. These observations indicate that the reaction is posttranslational and is not secondary to conversion of isotopic acetate into amino acids. The posttranslational nature of tubulin acetylation was further established by the demonstration that acetate is incorporated into $\alpha$-tubulin in neurites, which lack the capacity for cytoplasmic protein synthesis. Finally, a monoclonal antibody that is specific for acetylated $\alpha$-tubulin (Piperno and Fuller, 1985) recognizes the acidic variants of $\alpha$-tubulin of cultured neurons that can be labeled by incubation with ${ }^{3} \mathrm{H}$-acetate. Collectively, these observations indicate that $\alpha$-tubulin of cultured sympathetic neurons undergoes a posttranslational acetylation. Immunofluorescence analyses using a monoclonal antibody specific for acetylated $\alpha$-tubulin revealed that it was present throughout the neuron and showed no obvious regional compartmentalization. We have also shown that $\alpha$-tubulin is acetylated in the NGF-responsive PC12 line of pheochromocytoma cells using biochemical and immunological criteria. However, this modification was detected only in long-term (14 d) NGF-treated cells. The results are discussed in terms of the possible role of acetylation as a local mechanism for regulating microtubule stability.

Heterogeneity of neuronal tubulin is well documented. For example, brain tubulin from a variety of vertebrate sources can be resolved into a minimum of $6 \alpha$-tubulins and $12 \beta$-tubulins by high-resolution isoelectric focusing (Marotta et al., 1978;

\footnotetext{
Received July 25, 1986; revised Nov. 24, 1986; accepted Dec. 3, 1986.

We wish to thank Dr. Gianni Piperno, Rockefeller University, New York, N.Y., for providing a monoclonal antibody to acetylated $\alpha$-tubulin. The work reported here was supported by NIH Grants NS17681 and NS23530. Also, Dr. Black is the recipient of a Research Career Development Award from NIH.

Correspondence should be addressed to Dr. Mark M. Black, Department of Anatomy, Temple University School of Medicine, 3420 N. Broad Street, Philadelphia, PA 19140.

Copyright (C) 1987 Society for Neuroscience $0270-6474 / 87 / 061833-10 \$ 02.00 / 0$
}

Field et al., 1984; Sullivan and Wilson, 1984; Field and Lee, 1985). A similar variety of tubulin isoforms also has been observed in cultures of pure neurons (Gozes and Sweadner, 1981; Moura Neto et al., 1983) and also in single neurons grown in culture (Gozes and Sweadner, 1981). This heterogeneity reflects in part the existence of multiple tubulin genes (reviewed by Cleveland and Sullivan, 1985). However, the number of distinct tubulin polypeptides greatly exceeds the number of tubulin genes, indicating that additional mechanisms contribute to tubulin heterogeneity. One of these involves posttranslational modification of the primary translation product. Neuronal tubulin undergoes posttranslational modifications, including de-tyrosylation/tyrosylation (Raybin and Flavin, 1977; Arce et al., 1978) and phosphorylation (Eipper, 1972; Gard and Kirschner, 1985). Posttranslational modifications represent a means for dynamically altering the chemistry of tubulin and microtubules at sites spatially removed from the protein synthesis machinery. Such modifications are thought to contribute to the responsiveness of the microtubule network to local changes in the internal and external milieu.

Microtubules are prominent components of the axonal and dendritic cytoskeletons. These cytoskeletons provide the architectural framework that defines the external shape of these neurites. The principal site for the synthesis of tubulin and other cytoskeletal proteins of the neurites is the neuron cell body. The interval between the synthesis of these proteins and their arrival in the neurites is measured in hours to days to even weeks. The delivery of newly synthesized tubulin to the axon or dendrites is too slow to contribute to the dynamic responsiveness of the tubulin-microtubule system in these neurites to acute changes in their internal or external environment. Rather, local mechanisms, such as posttranslational modifications, must be of primary importance in this respect.

We have recently described a posttranslational modification of $\alpha$-tubulin in cultured sympathetic neurons that lowers its $\mathrm{p} I$ (Black and Kurdyla, 1983a). The present report expands upon this finding by showing that this modification is due to acetylation, that it occurs locally in the neurites of cultured neurons, and finally, that $\alpha$-tubulin is also acetylated in the neuron-like line of PC12 pheochromocytoma cells but only after prolonged exposure to NGF. Portions of the work presented here have been published previously in abstract form (Black and Keyser, 1986).

\section{Materials and Methods}

Cell culture and metabolic labeling. Sympathetic neurons were obtained from superior cervical ganglia of 1- to 5-d-old rat pups and grown as 


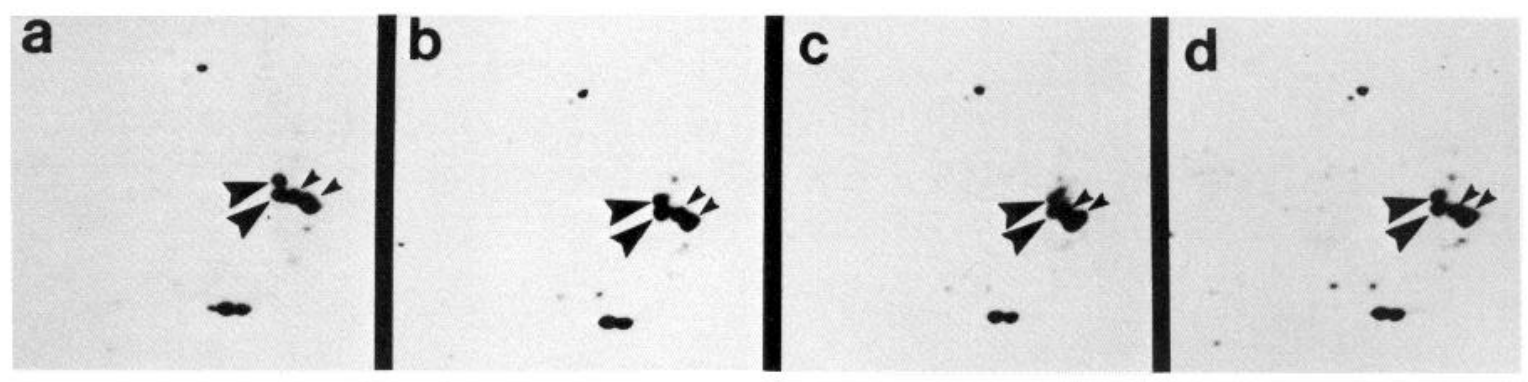

Figure 1. Pulse-chase analyses of tubulin in cultured neurons. Shown are portions of fluorographs depicting the tubulin region of 2-D gels of whole-cell SDS extracts of cultured neurons pulse-labeled with ${ }^{35} \mathrm{~S}$-methionine for $1 \mathrm{hr}$ and then chased in the absence of label for $0 \mathrm{hr}(a), 3 \mathrm{hr}$ (b), $20 \mathrm{hr}(\mathrm{c})$, or $20 \mathrm{hr}$ in the presence of $2 \mu \mathrm{g} / \mathrm{ml}$ podophyllotoxin $(d)$. The large arrowheads identify the $2 \alpha$-tubulins, while the small arrowheads identify the $2 \beta$-tubulins. Note that the appearance of the labeled $\alpha$-tubulins in the 2-D gels changes as a function of the chase time; with no chase or with short chase times, the $\alpha$-tubulins focus as discrete spots, while after prolonged chase times, they focus as short streaks. Also, the conversion of spot to streak morphology does not occur when microtubule depolymerizing drugs are included in the chase medium.

dissociated or explant cultures as described previously (Black et al., 1984; Peng et al., 1986). Non-neuronal cells were eliminated by treatment with cytosine arabinoside and fluorodeoxyuridine; the resulting cultures typically consisted of $\geq 97 \%$ neurons. PC1 2 cells were obtained from Dr. Lloyd A. Greene (Department of Pharmacology, New York University Medical Center, New York, NY) and grown as described previously (Black et al., 1986b).

Cultures were pulse-labeled with ${ }^{35} \mathrm{~S}$-methionine (Amersham) and then chased in the absence of label as described previously (Black et al., 1986a). To identify acetylated proteins in intact neurons, cultures were rinsed twice with a basic salt solution (BSS) $(124 \mathrm{~mm} \mathrm{NaCl}, 12$ mм NaOH, $30 \mathrm{~mm}$ HEPES, $2 \mathrm{~mm} \mathrm{CaCl}$, $5 \mathrm{~mm} \mathrm{KCl,} 0.5 \mathrm{~mm} \mathrm{MgCl}_{2}$, $11 \mathrm{~mm}$ dextrose, $50 \mathrm{ng} / \mathrm{ml} \mathrm{NGF}$ ), incubated with fresh BSS for $30 \mathrm{~min}$ at $35^{\circ} \mathrm{C}$, and then incubated with fresh BSS containing $200 \mu \mathrm{Ci} / \mathrm{ml}$ of ${ }^{3} \mathrm{H}$-acetic acid, Na salt (ICN), for varying times at $35^{\circ} \mathrm{C}$. In some experiments, BSS was supplemented with $0.1 \mathrm{~mm}$ cycloheximide (Sigma) to inhibit protein synthesis or with unlabeled essential and nonessential amino acids, at levels found in modified Eagle's medium.

Immunological procedures. Immunoprecipitation was carried out by a modification of the procedure of Luca and Vallee (1985). Cultures labeled with ${ }^{35} \mathrm{~S}$-methionine or ${ }^{3} \mathrm{H}$-acetic acid were dissolved in hot $1 \%$ SDS containing protease inhibitors $[0.2$ trypsin inhibitory units of aprotinin and $10 \mu \mathrm{g} / \mathrm{ml}$ each of leupeptin, antipain, and chymostatin (Sig$\mathrm{ma})]$, clarified by centrifugation $(10 \mathrm{~min}$ at $12,000 \times \mathrm{g})$, and then chilled and diluted 1:10 with Tris-buffered saline (TBS) $(50 \mathrm{~mm}$ Tris, $\mathrm{pH} 7.6$, $150 \mathrm{~mm} \mathrm{NaCl}$ ) containing $1 \%$ (wt/vol) NP-40. The samples were then divided into appropriate aliquots, and each was incubated with primary antibody (as ascites) for $2 \mathrm{hr}$ on ice. The primary antibodies were mouse monoclonals against $\alpha$-tubulin or $\beta$-tubulin (Amersham), and they were used at dilutions of 1:100 to 1:500. Goat anti-mouse immunoglobulins coupled to agarose beads (HyClone) were preincubated with $1 \mathrm{mg} / \mathrm{ml}$ BSA in TBS with $1 \% \mathrm{NP}-40$ and were then added to each sample to harvest antibody-antigen complexes. After overnight incubation with gentle agitation at $4^{\circ} \mathrm{C}$, the beads were collected by centrifugation and then washed by 4 cycles of centrifugation and resuspension in TBS containing 1\% NP-40 and 2 m urea followed by 2 cycles with TBS. Labeled antigen was released from the beads by boiling in $2 \%$ SDS followed by centrifugation to sediment the beads. The resulting supernates were analyzed by PAGE.

Immunoblotting was performed as described previously (Peng et al., 1985), except that $5 \%$ instant nonfat dry milk (Carnation) was used to block protein binding sites on the nitrocellulose paper. Immunofluorescence was performed as described previously (Peng et al., 1986), except that neurons were grown on chamber slides (LabTek) coated first with $0.63 \%$ polyethylenimine (Sigma) in borate buffer, rinsed extensively with water and then Liebowitz medium (K.C. Biologicals), and then coated with collagen. In addition to the antibodies described above, we also used a mouse monoclonal antibody specific for acetylated $\alpha$-tubulin (Piperno and Fuller, 1985) for these analyses. Cultures were fixed either by immersion in $80 \mathrm{~mm}$ PIPES, pH $6.9,1 \mathrm{mM} \mathrm{MgSO}_{4}, 10 \mathrm{~mm}$ EGTA, $0.3 \%$ glutaraldehyde, $0.1 \%$ Empigen or in cold $\left(-20^{\circ} \mathrm{C}\right)$ acetone. In the former case, cultures were incubated with PBS containing $10 \mathrm{mg} /$ $\mathrm{ml} \mathrm{Na}$ borohydride prior to incubation with primary antibody.

Gel electrophoresis. One-dimensional SDS (1-D) and 2-dimensional isoelectric focusing $\times$ SDS (2-D) gel electrophoresis were performed as described previously (Black et al., 1984; Peng et al., 1985). Gels were stained with Coomassie blue and then processed for fluorography using Enhance (New England Nuclear) or DMSO-PPO (Bonner and Laskey, 1984).

\section{Results}

Tubulin of cultured sympathetic neurons can be resolved into 4 distinct species by $2-\mathrm{D}$ gel electrophoresis, $2 \alpha$-tubulins and $2 \beta$-tubulins (Black et al., 1984). Pulse-chase experiments show that the $\alpha$-tubulins undergo a posttranslational modification (Fig. 1 ; and Black and Kurdyla, 1983a). The labeled $\alpha$-tubulins of cultures pulse-labeled for $1 \mathrm{hr}$ focus as discrete spots (Fig. 1a). When such pulse-labeled cultures are chased in the absence of label for prolonged times, the $\alpha$-tubulins focus as short streaks (Fig. 1c). Attempts to resolve the streaks into multiple spots by varying ampholine sources and content, lysis buffer composition, and isoelectric focusing time were unsuccessful. The change in appearance of $\alpha$-tubulin was consistently observed in pulsechase experiments and, in such analyses, first became apparent with chase times of $\sim 6 \mathrm{hr}$ (Black and Kurdyla, 1983a; Black et al., 1986a). It could be prevented by including microtubule depolymerizing drugs in the chase medium (Fig. 1d), suggesting that microtubules are the preferred substrate for the modification.

By Coomassie blue staining, the $\alpha$-tubulins of cultured neurons appear as short streaks that are indistinguishable with respect to appearance and relative mobility in 2-D gels from the labeled $\alpha$-tubulins of cultures pulse-labeled and then chased overnight (compare Fig. $1 c$ with Fig. $4 a$ ). The labeled $\alpha$-tubulin of cultures pulse-labeled for $1 \mathrm{hr}$ overlies only the most basic region of the $\alpha$-tubulin streak visualized by Coomassie blue staining. Thus, the modification of $\alpha$-tubulin lowers its $\mathrm{p} I$.

Note that the appearance of the principal $\beta$-tubulin species in the 2-D gels also appeared to change in these pulse-chase experiments. We have not studied the basis for this change in detail, although it appears to occur in the presence of microtubule depolymerizing drugs (compare Fig. 1, $a$ and $d$ ).

\section{Acylation of $\alpha$-tubulin in intact neurons}

Two of the many types of posttranslational modification that could lower the $\mathrm{p} I$ of $\alpha$-tubulin are phosphorylation and acylation. These 2 modifications are of particular interest because there is evidence for the phosphorylation as well as acylation (specifically acetylation) of tubulin in other systems (Gard and Kirschner, 1985; L'Hernault and Rosenbaum, 1985). In anal- 


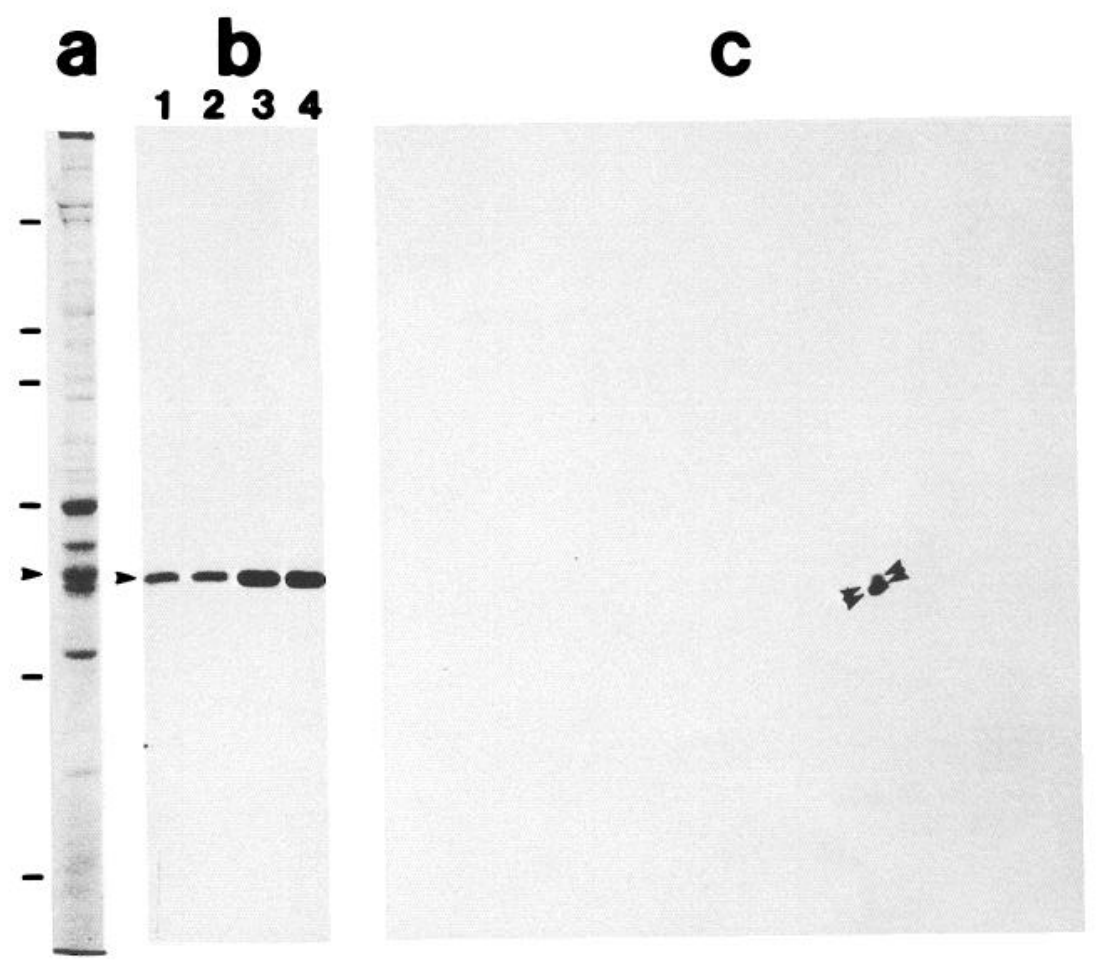

Figure 2. Acylation of proteins in cultured neurons. $a$, Representative 1-D gel profile of proteins in cultured neurons visualized by staining with Coomassie blue. The bars indicate the position of molecular weight standards, which correspond (from top to bottom) to apparent $M_{r}$ of 200,000 , $116,000,94,000,68,000,43,000$, and 30,000. The arrowhead identifies the position of $\alpha$-tubulin. $b$, Fluorograph of labeled proteins from cultures incubated with ${ }^{3} \mathrm{H}$-acetate for $30 \mathrm{~min}$ (lanes 1 and 2) or $90 \mathrm{~min}$ (lanes 3 and 4) in the absence (lanes 1 and 3 ) or presence (lanes 2 and 4 ) of 0.1 mM cycloheximide. The cultured neurons were dissolved in SDS sample buffer and then analyzed on an $8 \%$ gel. The arrowhead depicts the position of $\alpha$-tubulin. At the fluorographic exposure shown, a single labeled species is observed, and it comigrates with $\alpha$-tubulin. $c$, Fluorograph of a 2-D gel of labeled proteins from a culture incubated with ${ }^{3} \mathrm{H}$-acetate for $90 \mathrm{~min}$ in the presence of cycloheximide (the basic end of the gel is at left). The gel was stained with Coomassie blue and then treated with Enhance; under these conditions, the staining pattern is reasonably well preserved. The arrowheads depict the basic and acidic ends of the $\alpha$-tubulin streaks. The only labeled proteins observed comigrated with $\alpha$-tubulin, and they appeared to overlap only the acidic $1 / 2-2 / 3$ of the $\alpha$-tubulin streaks.

yses of neuronal proteins labeled in situ with ${ }^{32} \mathrm{P}_{\mathrm{i}}$, we did not detect a phosphoprotein with the mobility expected for phosphorylated $\alpha$-tubulin (Keen and Black, 1986, and unpublished observations). In contrast, incubation of cultures with ${ }^{3} \mathrm{H}$-acetate results in the prominent labeling of a protein that is very similar in mobility to $\alpha$-tubulin in 1-D gels. In 2-D gels this labeled protein resolves into 2 species that comigrate with the more acidic portion of the $\alpha$-tubulin streaks (Fig. 2). The identification of this protein as $\alpha$-tubulin was confirmed by immunoprecipitation analyses (Fig. 3). The degree of $\alpha$-tubulin labeling in cultures incubated with ${ }^{3} \mathrm{H}$-acetate was not detectably affected by including $0.1 \mathrm{~mm}$ cycloheximide in the incubation medium (Fig. $2 b$ ). At this level, cycloheximide inhibited the incorporation of amino acids into protein by $\geq 95 \%$ (data not shown). Thus, the incorporation of ${ }^{3} \mathrm{H}$-acetate into $\alpha$-tubulin is posttranslational and is not dependent on ongoing protein synthesis. The posttranslational nature of this reaction was unambiguously established in experiments that showed that pure neurite preparations, which lack the capacity for cytoplasmic protein synthesis (Black and Lasek, 1977; Estridge and Bunge, 1978), incorporate label into $\alpha$-tubulin when incubated with ${ }^{3} \mathrm{H}$ acetate (see Fig. $5 b$ ). Other proteins were also labeled in cultures incubated with ${ }^{3} \mathrm{H}$-acetate, although to a very minor degree compared to $\alpha$-tubulin (see Fig. 5b).

Protein labeling after incubation with ${ }^{3} \mathrm{H}$-acetate could occur by 2 general mechanisms. In one, acetate is taken up by the neurons and is converted to acetyl $\mathrm{CoA}$; the acetyl group is then transferred to appropriate acceptor proteins by specific acylases (Wold, 1981). Alternatively, the isotopic acetate may be metabolically converted to amino acids that are then transferred to appropriate acceptor proteins posttranslationally. Several considerations suggest that the labeling of $\alpha$-tubulin in cultured neurons after incubation in ${ }^{3} \mathrm{H}$-acetate is due to acylation and is not secondary to its conversion to amino acids. First, antibodies specific for $\alpha$-tubulin that is acylated (specifically acetylated) on lysine residues (Piperno and Fuller, 1985) recognize posttranslationally generated $\alpha$-tubulin of cultured neurons (Figs. 4, 9). Second, the principal amino acids synthesized from acetate are aspartic and glutamic acids. There is no evidence that these amino acids can be posttranslationally incorporated into $\alpha$-tubulin (Bara et al., 1973). The one amino acid that can be posttranslationally incorporated into $\alpha$-tubulin is tyrosine (Raybin and Flavin, 1977; Arce et al., 1978). Tyrosine is synthesized from phenylalanine, an essential amino acid, by hydroxylation. It is extremely unlikely that acetate could be involved in the hydroxylation of phenylalanine. Thus, on the basis of these considerations, it seems extremely unlikely that labeling of $\alpha$-tubulin following incubation with ${ }^{3} \mathrm{H}$-acetate is secondary to its conversion to amino acids. Nonetheless, to evaluate this possibility experimentally, we examined the degree of labeling that occurred in the presence or absence of unlabeled amino acids. The incubation medium was supplemented with either a complete mix of amino acids or tyrosine alone. Including these unlabeled amino acids in the incubation medium with 


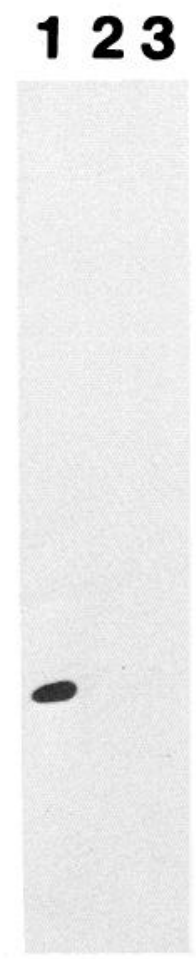

Figure 3. Immunoprecipitation of acylated $\alpha$-tubulin from cultured neurons. Neurons labeled with ${ }^{3} \mathrm{H}$-acetate for $90 \mathrm{~min}$ were dissolved in SDS. Three equal-sized aliquots were prepared from the sample, and each was subjected to immunoprecipitation as described in Materials and Methods. Shown is a fluorographic exposure of a 1-D gel analysis of the precipitates obtained with monoclonal antibodies to $\alpha$-tubulin (lane 1), $\beta$-tubulin (lane 2), or no primary antibody (lane 3). The acylated protein that comigrated with $\alpha$-tubulin was specifically precipitated by the antibody to $\alpha$-tubulin. In control experiments on ${ }^{35} \mathrm{~S}$-methionine-labeled cultures, the antibodies to $\alpha$ - and $\beta$-tubulin precipitated a single polypeptide that corresponded to $\alpha$ - or $\beta$-tubulin, respectively (data not shown).

${ }^{3} \mathrm{H}$-acetate had no detectable effect on the degree of labeling of $\alpha$-tubulin (data not shown). We conclude that $\alpha$-tubulin of cultured sympathetic neurons undergoes a posttranslational acylation. As argued in the Discussion, it is likely that the specific acylation reaction is an acetylation.

To determine if the acylated $\alpha$-tubulin corresponded to the posttranslationally generated species of $\alpha$-tubulin seen in the pulse-chase experiments with ${ }^{35} \mathrm{~S}$-methionine (see Fig. 1), wholecell SDS extracts of cultured neurons were prepared and subjected to 2-D gel electrophoresis; the resulting gel was stained with Coomassie blue. The $\alpha$-tubulin streaks were excised from the gel and divided into basic and acidic portions, corresponding to unmodified and modified forms, respectively. Figure $4 a$ shows a portion of a representative stained gel that illustrates the position of the $\alpha$-tubulin streaks and how they were divided into basic $(+)$ and acidic $(-)$ portions. The gel pieces were equilibrated with SDS, loaded onto an $8 \%$ gel, electrophoresed in the standard manner, and then transfered to nitrocellulose paper. The resulting transfers were probed with either a general $\alpha$-tubulin antibody, in that it recognized both acylated and nonacylated $\alpha$-tubulin, or the antibody specific for acetylated $\alpha$-tubulin. Both the basic and acidic portions of the $\alpha$-tubulin streaks reacted with the general $\alpha$-tubulin antibody (Fig. $4 b$ ). The reaction with the acidic portion is slightly greater than with the

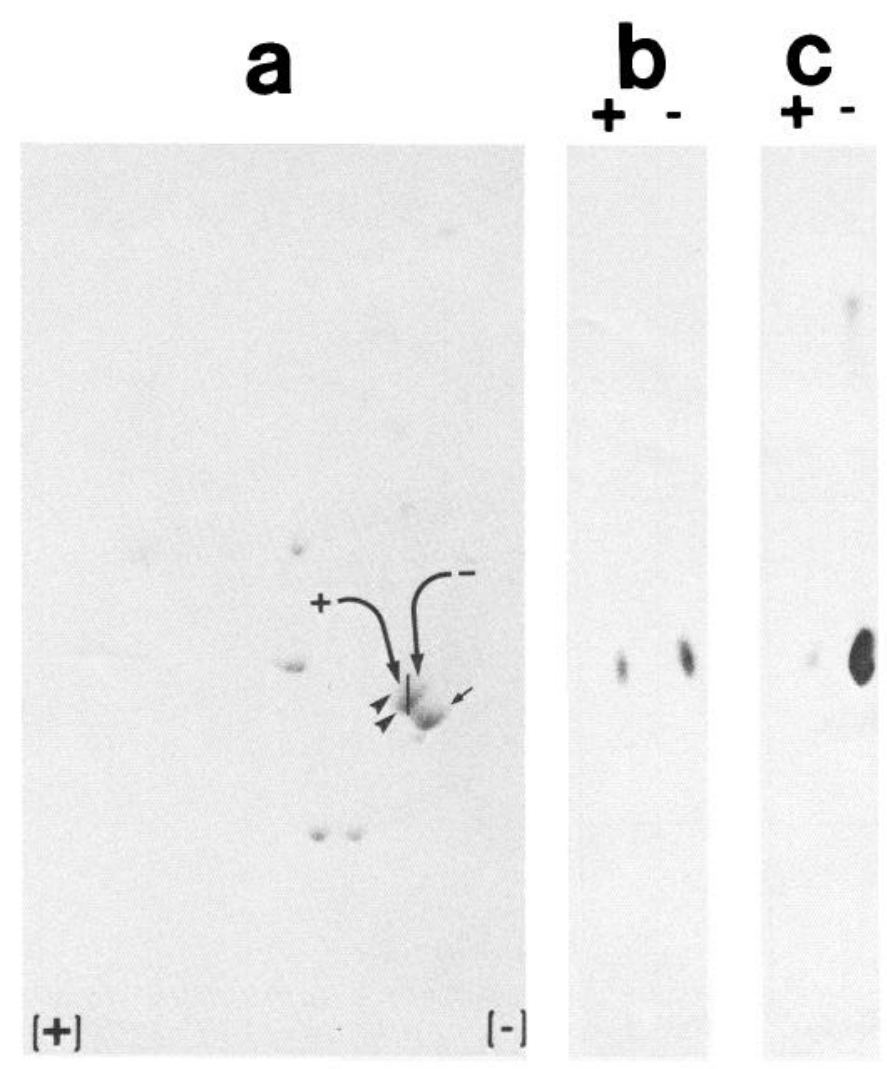

Figure 4. Analysis of $\alpha$-tubulin of cultured neurons by immunoblotting with a general $\alpha$-tubulin antibody and with an antibody specific for acetylated $\alpha$-tubulin. Whole-cell SDS extracts of cultured neurons were subjected to 2-D gel electrophoresis, and the resulting gels were stained with Coomassie blue. The $\alpha$-tubulin streaks were excised from the gels and cut into basic and acidic portions. The major $\beta$-tubulin spot was also excised from the gels. The gel pieces were equilibrated in a buffer consisting of $2 \%$ SDS, $0.1 \mathrm{~m}$ Tris, $\mathrm{pH} 6.8$, and $5 \% \beta$-mercaptoethanol for $3 \mathrm{hr}$, loaded onto a 1-D gel consisting of $8 \%$ acrylamide, electrophoresed in the standard manner, transferred to nitrocelluose paper, and then probed with either a general monoclonal antibody to $\alpha$-tubulin or with the monoclonal antibody specific for acetylated $\alpha$-tubulin. $a$, Picture of one of the Coomassie blue-stained gels used in this analysis. The arrowheads are positioned at the basic ends of the $\alpha$-tubulin streaks. The vertical line shows where the $\alpha$-tubulin streaks were divided into basic $(+)$ and acidic $(-)$ portions. The small arrow identifies the major $\beta$-tubulin spot. The immunoblots obtained with the general $\alpha$-tubulin antibody and with antibody to acetylated $\alpha$-tubulin are depicted in $b$ and $c$, respectively. The general $\alpha$-tubulin antibody recognized both the basic and acidic portions of the $\alpha$-tubulin streaks equally well $(b)$. In contrast, the antibody to acetylated $\alpha$-tubulin recognized the acidic portion of the $\alpha$-tubulin streaks much more strongly than the basic portion. The lanes with $\beta$-tubulin showed no immunoreactivity with either antibody (not shown).

basic portion, consistent with the observation that the acidic portion of the $\alpha$-tubulin streak contains slightly more protein than the basic portion (see Fig. 4a). In contrast, the antibody to acetylated $\alpha$-tubulin, which shows little cross-reactivity with nonacetylated derivatives of $\alpha$-tubulin (Piperno and Fuller, 1985), reacted with the acidic portion of the $\alpha$-tubulin streak very strongly but barely recognized its basic portion (Fig. $4 c$ ). These observations demonstrate that the acidic portion of the $\alpha$-tubulin streak contains acetylated tubulin, while the basic portion contains little, if any, acetylated $\alpha$-tubulin. Thus, the posttranslation shift in mobility of $\alpha$-tubulin seen in the pulse-chase experiments (Fig. 1) is due at least in part to acetylation. 


\section{Localization of acetylated $\alpha$-tubulin in cultured neurons}

In one series of experiments, explant cultures were used as a model system for direct analyses of acetylated $\alpha$-tubulin in cell bodies and neurites. Explant cultures consist of a centrally situated ganglionic explant or cell body mass (CBM) that is $\sim 0.5$ $\mathrm{mm}$ in diameter and contains all of the neuron cell bodies. Surrounding the CBM is a cell-body-free halo of neurites that extends for 4-6 $\mathrm{mm}$ in all directions (Peng et al., 1986). Cell bodies were physically separated from neurites by dissecting the CBM from the cultures. Immunoblotting analyses using the monoclonal antibody specific for acetylated $\alpha$-tubulin revealed acetylated $\alpha$-tubulin in both CBM and neurite preparations, in roughly equal amounts (Fig. $5 a$ ). Comparable distribution patterns were also obtained in immunoblots of CBM and neurite preparations obtained with more general antibodies against $\alpha$ and $\beta$-tubulin (Peng et al., 1986). Thus, acetylated $\alpha$-tubulin is present in both cell bodies and neurites, and its distribution between these regions closely resembles that of total tubulin. Similar conclusions were also reached in immunostaining analyses on dissociated cultures (Fig. 6). In these latter analyses, all neurons in the cultures as well as their neurites stained intensely. In contrast, the staining of non-neuronal cells (fibroblasts and Schwann cells) was indistinguishable from background (data not shown).

We have also used explant cultures to determine whether $\alpha$-tubulin undergoes acetylation in cell bodies and neurites or in just one of these regions. Explant cultures were incubated with ${ }^{3} \mathrm{H}$-acetate and separated into $\mathrm{CBM}$ and neurites, and the resulting preparations were assayed for ${ }^{3} \mathrm{H}$-acetylated $\alpha$-tubulin by PAGE and fluorography. The results (Fig. $5 b$ ) show that $\alpha$-tubulin is acetylated locally in the neurites as well as in the cell bodies. Identical observations were obtained when cultures were incubated with ${ }^{3} \mathrm{H}$-acetate in the absence or presence of $0.1 \mathrm{~mm}$ cycloheximide.

\section{Acylation of $\alpha$-tubulin in PC12 cells}

We have previously reported that the $\alpha$-tubulins of PC12 cells grown without NGF [PC12(-) cells] or with NGF for 3 weeks $[\mathrm{PC} 12(+)$ cells] differ from each other with respect to appearance in 2-D gels (Black et al., 1986b). In the present report, we show that this difference is due to acylation.

$\alpha$-Tubulins of PC12(-) cells focus as discrete spots in 2-D gels, while the $\alpha$-tubulins of PC12(+) cells focus as short streaks (Fig. 7; and Black et al., 1986b). These differences are apparent in mixing experiments (Fig. 7), indicating that the difference in 2-D gel behavior of $\alpha$-tubulins from PC12(-) and PC12(+) cells is due to differences in the tubulins themselves. By Coomassie blue staining, the $\alpha$-tubulins of the mixed samples were indistinguishable from each other and closely resembled in appearance the labeled $\alpha$-tubulins of PC12(+) cells (Fig. $7 b$ ). In contrast, the labeled $\alpha$-tubulins of $\mathrm{PC} 12(-)$ cells overlapped only the basic portion of the Coomassie blue-stained $\alpha$-tubulin.

The $\alpha$-tubulins of $\mathrm{PC} 12(-)$ cells resemble, in electrophoretic mobility, the unmodified $\alpha$-tubulins of neurons (compare Fig. $7 a$ with Fig. $1 a$ ), while the $\alpha$-tubulins of PC12(+) cells resemble the total $\alpha$-tubulin (modified plus unmodified) subunits of neurons (compare Fig. $7 b$ with Figs. $1 c$ and $4 a$ ). These considerations raise the possibility that the $\alpha$-tubulins of PC12(+) cells are acylated, whereas in $\mathrm{PC} 12(-)$ cells they are not. To begin testing this possibility, we have used pulse-chase protocols to determine whether the $\alpha$-tubulins of PC12 cells grown with or

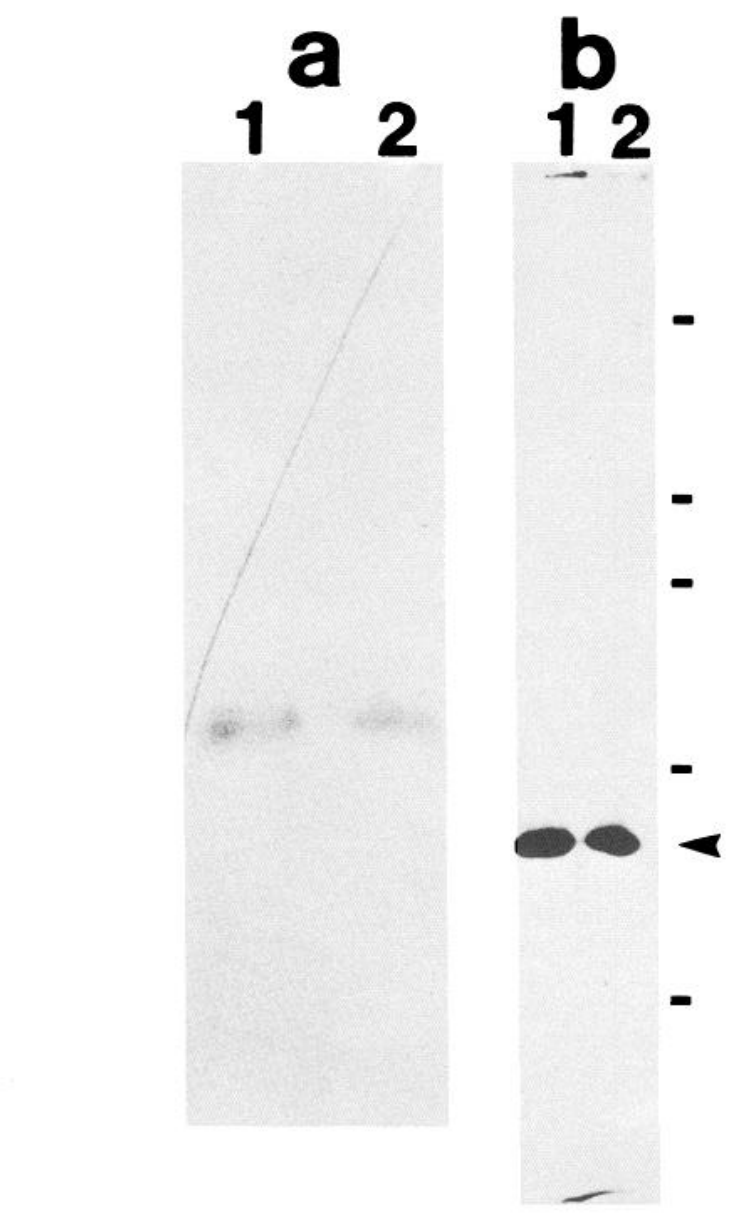

Figure 5. Distribution of acetylated $\alpha$-tubulin in explant cultures. $a$, Nitrocellulose transfer of an $8 \%$ gel of the CBM and neurite preparations from an explant culture (see text for details) were probed with the antibody against acetylated $\alpha$-tubulin. The immunoreactive material in the CBM and neurite material are depicted in lanes 1 and 2 , respectively. A single reactive species was detected in each preparation, and it appeared to be equally distributed between the CBM and neurites. Similar distribution patterns were also obtained with other monoclonal antibodies to $\alpha$-tubulin (which recognized both acylated and nonacylated isoforms) and $\beta$-tubulin (Peng et al., 1986, and data not shown). $b$, CBM and neurites were prepared from an explant culture labeled with ${ }^{3} \mathrm{H}$ acetate for $90 \mathrm{~min}$, dissolved in SDS sample buffer, and subjected to gel electrophoresis (on an $8 \%$ gel) and fluorography. The labeled proteins in the CBM and neurites are depicted in lanes 1 and 2 , respectively. The bars indicate the position of molecular weight standards (see Fig. 2 ), and the arrowhead identifies the position of $\alpha$-tubulin. Note that $\alpha$-tubulin is acetylated in both CBM and neurites. Also some additional minor labeled acylated proteins, apparent $M_{r} \sim 200,000$, can be detected in both CBM and neurites.

without NGF undergo a posttranslational modification that alters their mobility in 2-D gels. As shown in Figure $8, e-g$, the electrophoretic behavior of the $\alpha$-tubulins of PC12(-) cells did not detectably change as a function of the chase time. In contrast, the 2-D gel appearance of the $\alpha$-tubulins of PC12(+) cells was dependent on the labeling conditions (Fig. 8, $a-c$ ); with short pulse-labels, the $\alpha$-tubulins focused as discrete spots, while in cultures pulse-labeled and then chased for long times, these proteins focused as short streaks having a lower $\mathrm{p} I$ than the newly synthesized $\alpha$-tubulins. The change from spot to streak morphology was first apparent with chase times of $\sim 4 \mathrm{hr}$. In other pulse-chase experiments, this posttranslational modifi- 
Figure 6. Immunostaining analysis of the distribution of acetylated $\alpha$-tubulin in dissociated neuron cultures. Phase and corresponding immunofluorescent images of cultures stained with monoclonal antibody to acetylated $\alpha$-tubulin $(a$ and $b$ ) or with a general monoclonal antibody to $\alpha$-tubulin ( $c$ and $d$ ). The cells were fixed with glutaraldehyde as described in Materials and Methods. The cell bodies and neurites are at different focal planes, and most of the neurites seen in these images actually represent fascicles of several neurites. Both antibodies intensely stained all neurons and their neurites. Controls in which primary antibody was omitted showed no detectable fluorescence (not shown). Comparable images were obtained with cells fixed by immersion in cold acetone.
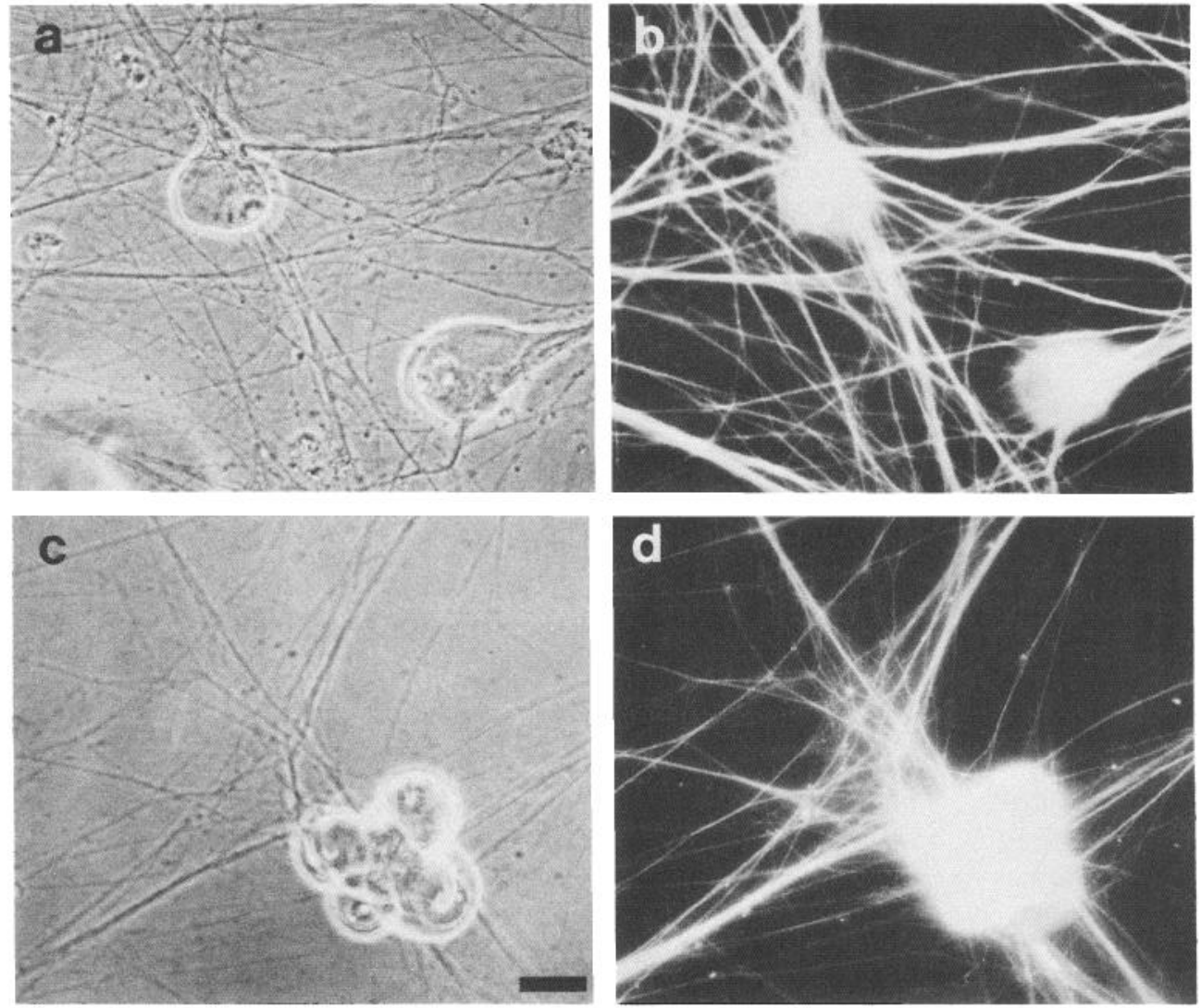

cation was observed in cells grown with NGF for $13 \mathrm{~d}$ but not in cells grown with NGF for $7 \mathrm{~d}$. This time course is markedly different from that of neurite outgrowth, which begins within 2-4 d of NGF treatment, and is quite extensive by $7-10 \mathrm{~d}$ with NGF.

The posttranslational modification of $\alpha$-tubulin in PC12(+) cells resembles the acetylation of $\alpha$-tubulin in cultured neurons in that the modification lowers the $\mathrm{p} I$ of $\alpha$-tubulin, occurs with a prolonged time course, and, as shown in Figure $8 d$, can be blocked by inhibitors of tubulin assembly, such as podophyllotoxin. To determine whether the $\alpha$-tubulins of PC12(+) cells are acylated, whole-cell SDS extracts of such cultures were probed for acetylated $\alpha$-tubulin by immunoblotting using the antibody against acetylated $\alpha$-tubulin. As shown in Figure 9, a single immunoreactive species was apparent in blots of PC12(+) cells (lane 1), and it closely resembled acetylated $\alpha$-tubulin of cultured neurons in mobility in 1-D gels (compare lanes 1 and 2). Similar immunoblotting analyses with $\mathrm{PC} 12(-)$ cells failed to reveal acetylated $\alpha$-tubulin (data not shown). In addition, when PC12(+) cultures were incubated with ${ }^{3} \mathrm{H}$-acetate and then analyzed by 1-D PAGE and fluorography, a single labeled species was detected, and it comigrated with $\alpha$-tubulin (Fig. 9, lane 3).

\section{Discussion}

\section{$\alpha$-Tubulin of cultured neurons undergoes acetylation}

Cultures incubated with ${ }^{3} \mathrm{H}$-acetate incorporate label into a protein that comigrates with $\alpha$-tubulin in 1-D and 2-D gels (Fig. 2) and that can be immunoprecipitated by a monoclonal antibody against $\alpha$-tubulin (Fig. 3). This incorporation occurs equally well in the presence or absence of cycloheximide at levels sufficient to inhibit protein synthesis by $\geq 95 \%$ (Fig. 2), indicating that it is a posttranslational reaction. This latter point is unambiguously confirmed by the demonstration that neurites, which lack the capacity for cytoplasmic protein synthesis (Black and Lasek, 1977; Estridge and Bunge, 1978), incorporate label from ${ }^{3} \mathrm{H}$ acetate into $\alpha$-tubulin (Fig. $5 b$ ). The reaction also occurs equally well in the presence or absence of unlabeled amino acids, indicating that the incorporation of label from ${ }^{3} \mathrm{H}$-acetate is not secondary to its conversion to amino acids. Finally, the posttranslationally modified $\alpha$-tubulin is recognized by a monoclonal antibody specific for acetylated $\alpha$-tubulin (Fig. 4). We conclude that $\alpha$-tubulin undergoes a posttranslational acylation in cultured neurons. This modification also occurs in the neuron-like PC12 pheochromocytoma cell line (Fig. 9), cultured rat hippocampal neurons (M. M. Black and G. A. Banker, unpublished observations), rat brain (M. M. Black, unpublished observations), neurons of amphibian retina (Sale et al., 1986), and nervous tissue of Drosophila (Piperno and Fuller, 1985). Thus, acylation of $\alpha$-tubulin is widespread in neurons. In the cultured sympathetic neurons used in the present studies, the majority of the $\alpha$-tubulin appears to be acylated (Fig. 4).

The specific acyl moiety incorporated into $\alpha$-tubulin of cultured sympathetic neurons has not been directly determined; it could be acetate itself or a fatty acid derivative of acetate. The acylation of $\alpha$-tubulin has been studied extensively in Chlamydomonas, in which it has been shown to be specifically acetylation (L'Hernault and Rosenbaum, 1985). Also, the tubulin acylase has been partially purified and characterized (Greer et al., 1986); under in vitro conditions, it transfers acetate from acetyl CoA to $\alpha$-tubulin. On the basis of these observations in Chlamydomonas, it seems reasonable that the acylation of $\alpha$-tubulin in intact neurons described here involves the posttrans- 


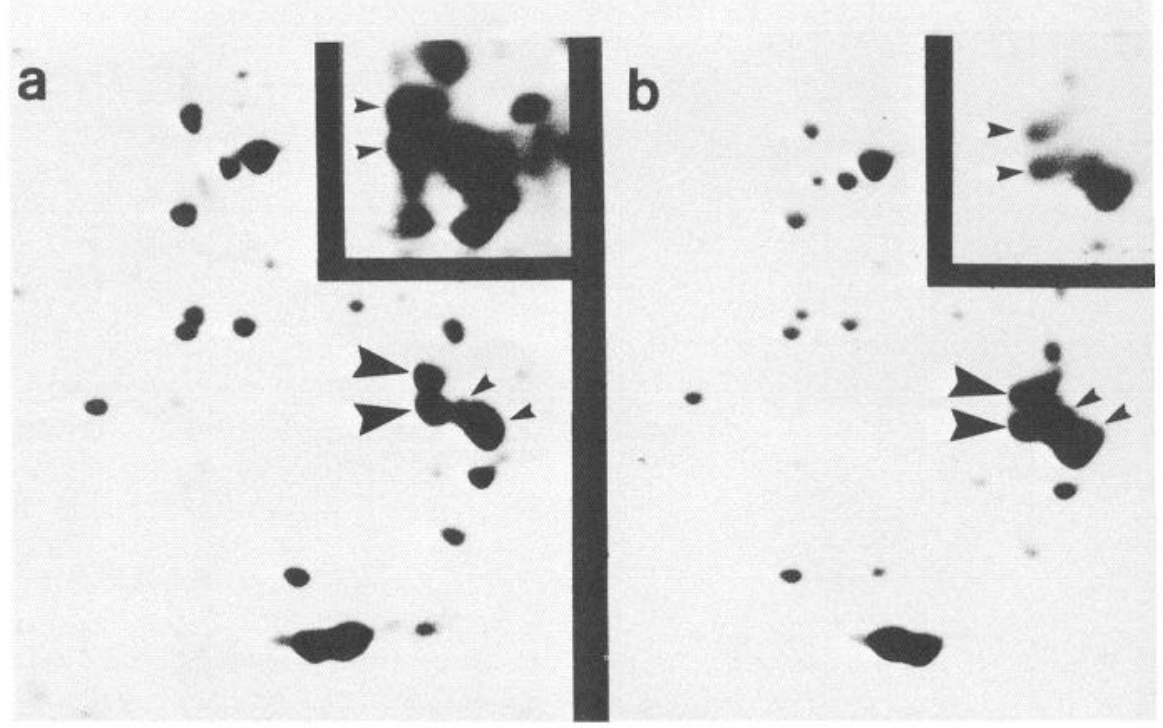

Figure 7. 2-D gel profiles of tubulin of PC12 cells grown without NGF or with NGF for $21 \mathrm{~d}$. Soluble extracts were prepared from labeled (24 $\mathrm{hr}$ with ${ }^{35} \mathrm{~S}$-methionine) and unlabeled $\mathrm{PCl} 2(-)$ and $\mathrm{PC1} 2(+)$ cells as described previously (Black et al., 1986b). The extracts contained $\sim 95 \%$ of the total tubulin in the cells. The labeled material from the PC12(-) cells was mixed with the unlabeled material from PC12(+) cells, while the labeled material from $\mathrm{PC} 12(+)$ cells was mixed with unlabeled material from PC12(-) cells. The mixed samples, which differed only in the source of the labeled proteins, were analyzed by 2-D gel electrophoresis, the resulting gels were stained with Coomassie blue, and labeled proteins were visualized by autoradiography. $a$, and $b$, Tubulin region of the autoradiographs depicting the labeled material in $\mathrm{PC12}(-)$ and $\mathrm{PC} 12(+)$ cells, respectively. The large arrowheads identify the $\alpha$-tubulins and the small arrowheads identify the $\beta$-tubulins. Note that labeled $\alpha$-tubulins of PC12(-) cells differ in appearance from those of $\mathrm{PC} 12(+)$ cells and that this difference is also apparent in comparisons of heavily exposed autoradiographs of PC12(-) cell tubulin (inset in $a$ ) with light exposures of $\mathrm{PC} 12(+)$ cell tubulin (inset in $b$ ); the arrowheads in the insets identify the $\alpha$-tubulins. Note also that in these mixing experiments, the $\beta$-tubulins of PC12 $(-)$ and $\mathrm{PC} 12(+)$ cells appeared slightly different from each other. We have not studied the basis for this.

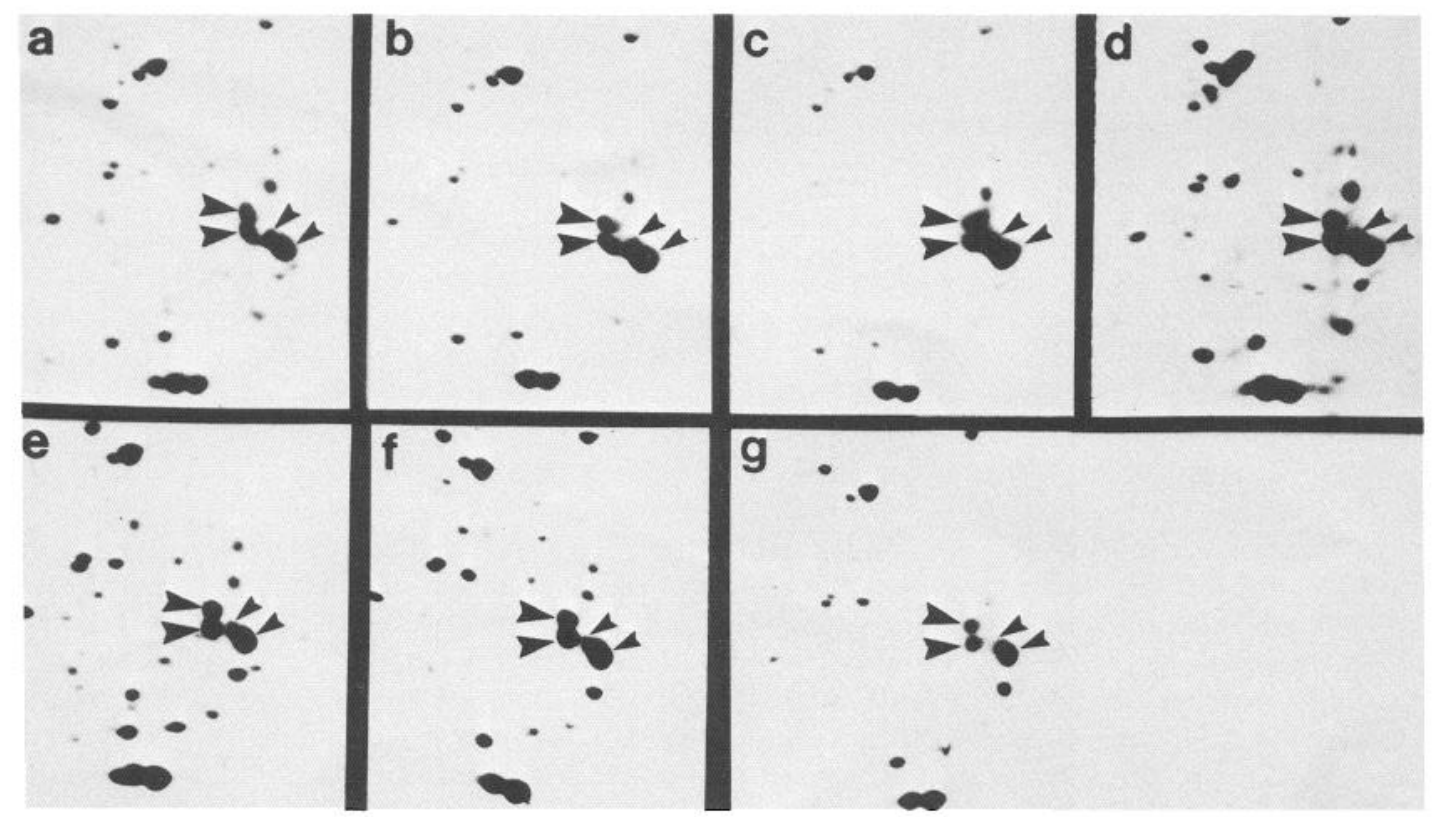

Figure 8. Pulse-chase experiments on the $\alpha$-tubulins of $\mathrm{PC12}(-)$ and $\mathrm{PC} 12(+)$ cells. PC12(-) and PC12(+) cells were pulse-labeled with ${ }^{35} \mathrm{~S}$ methionine for $1 \mathrm{hr}$ and then chased in the absence of label for varying times. At the end of the chase period, soluble extracts were prepared from the cells, resolved on 2-D gels, and autoradiographed to visualize labeled proteins. Shown is the tubulin containing region of autoradiographs prepared from such gels. $a-d$, Results obtained with PC12(+) cells chased for $0 \mathrm{hr}(a), 4 \mathrm{hr}(b), 22 \mathrm{hr}(c)$, and $22 \mathrm{hr}$ with $2 \mu \mathrm{g} / \mathrm{ml}$ podophyllotoxin in the chase medium $(d) . e-g$, Results obtained with PC12(-) cells processed after chase times of $0(e), 7.5(f)$, and $22 \mathrm{hr}(g)$. There was no detectable change in the 2-D gel behavior of $\alpha$-tubulin in PC12(-) cells in these pulse-chase experiments. In contrast, the 2-D gel appearance of $\alpha$-tubulin of $\mathrm{PC} 12(+)$ cells changed as a function of the chase period, and this change could be prevented by including microtubule depolymerizing drugs in the chase medium. 


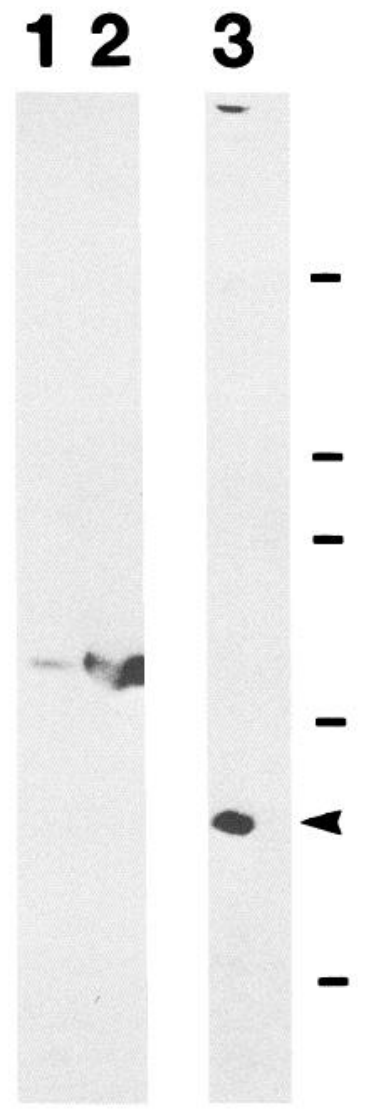

Figure 9. $\alpha$-Tubulin of PC12(+) cells is acetylated. Lanes 1 and 2, Immunoblots of whole-cell SDS extracts of PC12(+) cells (lane 1) and cultured neurons (lane 2) probed with the antibody against acetylated $\alpha$-tubulin. The samples were resolved on an $8 \%$ gel. A single immunoreactive species was detected in $\mathrm{PC} 12(+)$ cells, and it closely resembled acetylated $\alpha$-tubulin of cultured neurons in mobility in 1-D gels. Lane 3, Fluorograph depicting the labeled proteins in PC12(+) cells incubated with ${ }^{3} \mathrm{H}$-acetate for $90 \mathrm{~min}$. The cells were dissolved in SDS sample buffer, and the resulting sample was resolved on an $8 \%$ gel. The tracking dye was deliberately run off of the gel to enhance the separation of $\alpha$-and $\beta$-tubulins (this is why the position of the acylated $\alpha$-tubulin in lane 3 differs from that in lanes 1 and 2). The bars and arrow refer to lane 3 only and indicate the positions of molecular weight standards and $\alpha$-tubulin, respectively. A single labeled species was detected that comigrated with $\alpha$-tubulin.

lational incorporation of acetate. This possibility is fully supported by the observation that the monoclonal antibody specific for acetylated $\alpha$-tubulin recognizes the acylated $\alpha$-tubulin of cultured neurons (Fig. 4).

Acetylation of proteins can occur at either the $\alpha$-amino group of the amino terminal amino acid or the $\epsilon$-amino group of lysine. The following considerations indicate that that acetylation of $\alpha$-tubulin in neurons occurs principally on the $\epsilon$-amino group of lysine. First, newly synthesized $\alpha$-tubulin of cultured neurons first becomes acetylated $\sim 6 \mathrm{hr}$ after its synthesis. This time period is much longer than that typically observed for the synthesis and amino terminal acetylation of proteins, which generally occurs cotranslationally (Wold, 1981). The cotranslational occurrence of amino terminal acetylation reflects the localization of the enzymes that catalyze this reaction, which are associated with ribosomes (Wold, 1981). Second, the monoclonal antibody that selectively recognizes acetylated $\alpha$-tubulin of cultured neurons is apparently specific for tubulin acetylated on lysine residues (Piperno and Fuller, 1985).

\section{Acetylated $\alpha$-tubulin is present in cell bodies and neurites}

In immunostaining analyses on dissociated neurons, antibody specific for acetylated $\alpha$-tubulin localized to neuron cell bodies and apparently all of their neurites (Fig. 6). Similar observations were also obtained with explant cultures, in which acetylated $\alpha$-tubulin was identified in CBM and neurite halos using direct biochemical methods (Fig. 5). These latter experiments also showed that acetylation of $\alpha$-tubulin occurs in both cell bodies and neurites of cultured neurons. In both the immunostaining and biochemical analyses, acetylated $\alpha$-tubulin appeared uniformly distributed between cell bodies and neurites. Also, the distribution of acetylated $\alpha$-tubulin in the neurons was not detectably different from that of total tubulin. Thus, acetylated $\alpha$-tubulin does not exhibit any obvious regional compartmentalization within cultured sympathetic neurons. This was further confirmed by immunolocalization of acetylated $\alpha$-tubulin in cultured hippocampal neurons. These neurons produce typical axonal and dendritic neurites in culture that can be readily distinguished with phase optics (Bartlett and Banker, 1984). The monoclonal antibody specific for acetylated $\alpha$-tubulin stains cell bodies, axons, and dendrites of cultured hippocampal neurons (M. M. Black and G. A. Banker, unpublished observations).

An earlier study by Brown et al. (1982) raised the possibility that $\alpha$-tubulin undergoes posttranslational modification in axons. The present results definitively establish that $\alpha$-tubulin is posttranslationally modified in neurites by acetylation (Fig. 5). In addition, tyrosylation of $\alpha$-tubulin and phosphorylation of $\beta$-tubulin also occur in neurites of explant cultures (M. M. Black and $\mathrm{P}$. Keyser, unpublished observations). These posttranslational modifications may be involved in modulating various properties of the microtubule network locally within neurites in response to changes in the internal or external milieu.

\section{$N G F$ regulates the $\alpha$-tubulins of $P C 12$ cells}

The $\alpha$-tubulins of $\mathrm{PC} 12(+)$ cells differ from those of $\mathrm{PC} 12(-)$ cells with respect to mobility in 2-D gels (see Fig. 7), and this difference reflects a posttranslational modification that is expressed by $\mathrm{PC} 12(+)$ cells but not by $\mathrm{PC} 12$ cells grown without NGF (Fig. 8). This modification is at least in part due to acetylation, in that a protein of $\mathrm{PC} 12(+)$ cells that comigrates with $\alpha$-tubulin is recognized by the monoclonal antibody specific for acetylated $\alpha$-tubulin and is prominently labeled in $\mathrm{PC} 12(+)$ cultures incubated with ${ }^{3} \mathrm{H}$-acetate (Fig. 9). The modification in $\mathrm{PC} 12(+)$ cells resembles $\alpha$-tubulin acetylation in neurons in its effect on $\alpha$-tubulin mobility in 2-D gels, its sensitivity to microtubule depolymerizing agents, and the prolonged time between synthesis and acetylation of $\alpha$-tubulin.

The relationship between NGF-induced tubulin acetylation and neurite outgrowth is unclear. Acetylation of $\alpha$-tubulin becomes readily detectable only after 2 weeks with NGF. In contrast, the initiation of neurite outgrowth begins between 2-4 d with NGF, and by 7-10 d with NGF, the cells have elaborated an extensive neurite network. These considerations suggest that the appearance of acetylated $\alpha$-tubulin may not be coupled to early events in neurite outgrowth. However, it is also possible that acetylation of $\alpha$-tubulin occurs in concert with neurite outgrowth but that, at early times, only a minor fraction of $\alpha$-tubulin is acetylated and is undetectable with the methods used here. In this regard, acetylated $\alpha$-tubulin is primarily a polymer-specific variant (Black and Keyser, 1986), and at early phases of neurite outgrowth the relative levels of total tubulin in polymer, 
as well as the total levels of polymer, are quite low compared to later phases (Drubin et al., 1985; Black et al., 1986b). Immunostaining analyses of $\mathrm{PCl} 2$ cells after varying times with NGF, using antibodies specific for acetylated $\alpha$-tubulin, may resolve these possibilities.

\section{Functional considerations of $\alpha$-tubulin acetylation}

The time interval between the synthesis and initial acetylation of $\alpha$-tubulin in cultured sympathetic neurons is $\sim 6 \mathrm{hr}$ (Figs. 1, 8; Black and Kurdyla, 1983a). This is considerably longer than the time interval between the synthesis and assembly of tubulin. Using pulse-chase and extraction protocols, we have determined that newly synthesized tubulin reaches maximal levels in polymer $(\sim 75 \%)$ within $\sim 2$ hr of its synthesis (Black et al., 1986a). In 2-D gels, the labeled unassembled and assembled $\alpha$-tubulins of cells pulse-labeled for $10 \mathrm{~min}$ and then chased for $2 \mathrm{hr}$ focus as discrete spots that correspond in mobility to unacetylated $\alpha$-tubulin; none of this tubulin exhibits the electrophoretic properties of acetylated $\alpha$-tubulin (Fig. 1 in Black et al., 1986a). Thus, in neurons, the initial acetylation of newly synthesized $\alpha$-tubulin is not temporally coupled to its initial assembly in any direct manner.

Although acetylation of $\alpha$-tubulin is apparently not coupled to its assembly, the reaction can be prevented by treatment with microtubule depolymerizing drugs (Figs. 1, 8; L'Hernault and Rosenbaum, 1983). This observation raises the possibility that assembled tubulin, as opposed to unassembled tubulin, is the preferred substate for the acetylation reaction. This possibility is further supported by the observations that acetylated tubulin partitions almost entirely with the cytoskeleton in extraction assays that scparatc unassembled and assembled tubulin (Black and Keyser, 1986) and that tubulin polymer is a better substrate for partially purified $\alpha$-tubulin acetylase of Chlamydomonas than tubulin dimer (Maruta et al., 1986). Thus, the acetylation of $\alpha$-tubulin in intact neurons appears to represent a modification of preformed microtubules.

Acetylation of assembled $\alpha$-tubulin may increase the stability of microtubules (L'Hernault and Rosenbaum, 1983; Piperno and Fuller, 1985; LeDizet and Piperno, 1986). Acetylated $\alpha$-tubulin is commonly found in microtubule systems that are relatively stable to depolymerizing conditions. For example, ciliary and flagellar microtubules, which are highly resistant to conventional microtubule depolymerizing treatments (Behnke and Forer, 1967), contain principally acetylated forms of $\alpha$-tubulin (L'Hernault and Rosenbaum, 1983; Piperno and Fuller, 1985). Also, the susceptibility of microtubules in PC12 cells to cold or colchicine-induced depolymerization is dramatically reduced following long-term treatment with NGF (Black and Greene, 1982), and there is a corresponding enhancement in the levels of acetylated $\alpha$-tubulin in these cells (Figs. 7-9). Analogous observations have also been obtained in Chlamydomonus, in which a subpopulation of cytoplasmic microtubules that contain acetylated $\alpha$-tubulin are more stable to depolymerizing drugs than microtubules that do not contain this tubulin form (LeDizet and Piperno, 1986). Finally, neuronal microtubules can be depolymerized by conventional microtubule depolymerizing agents (Black and Kurdyla, 1983b; Black et al., 1984). However, prolonged treatments ( $\geq 6 \mathrm{hr}$ ) are necessary to achieve appreciable depolymerization, and these times are substantially longer than those required to completely depolymerize cytoplasmic microtubules in most non-neuronal cells $(\leq 2 \mathrm{hr})$. Acetylated $\alpha$-tubulin is prominent in neurons (Fig. 4) and is readily detected by im- munostaining with antibodies specific for acetylated $\alpha$-tubulin (Fig. 6). In contrast, the same immunostaining methods reveal little or no acetylated $\alpha$-tubulin in fibroblasts and Schwann cells (M. M. Black, unpublished observations).

Acetylation of assembled $\alpha$-tubulin may affect microtubule stability directly or indirectly. In considering these 2 alternatives, it is relevant that purified flagellar tubulin from Strongylocentrotus purpuratus [which is presumably acctylated (Piperno and Fuller, 1985)] assembles in vitro into microtubules that are readily depolymerized by cold (Farrell and Wilson, 1978). Assuming that the purification procedures did not alter the acetylation state of the $\alpha$-tubulin, then this observation suggests that the proposed effects of $\alpha$-tubulin acetylation on microtubule stability are primarily indirect. This is further indicated by the observation that aceylation has no detectable effect on the in vitro temperature-dependent assembly or disassembly of microtubules (Maruta et al., 1986). One possibility is that acetylation of $\alpha$-tubulin enhances the interaction between tubulin and microtubule-associated proteins and thereby increases polymer stability.

Note added in proof: More recent analyses have revealed regional compartmentalization of acetylated $\alpha$-tubulin-containing microtubules, based on sensitivity to microtubule depolymerizing drugs. Acetylated tubulin-containing microtubules of the cell body are completely depolymerized by exposure to $2 \mu \mathrm{g} / \mathrm{ml}$ podophyllotoxin for $\sim 3 \mathrm{~h}$, while such microtubules in neurites are largely unaffected by such treatments. Thus, the relative stability of acetylated $\alpha$-tubulin-containing microtubules in neurites is greater than in cell bodies.

\section{References}

Arce, C. A., M. E. Hallak, J. A. Rodriguez, H. S. Barra, and R. Caputto (1978) Capability of tubulin and microtubules to incorporate and to release tyrosine and phenylalanine and the effects of the incorporation of these amino acids on tubulin assembly. J. Neurochem. 31: 205210.

Bara, H. S., J. A. Rodriguez, C. A. Arce, and R. Caputto (1973) A soluble preparation from rat brain that incorporates into its own proteins $\left[{ }^{14} \mathrm{C}\right]$ arginine by a ribonuclease-sensitive system and $\left[{ }^{14} \mathrm{C}\right]$ tyrosine by a ribonuclease-insensitive system. J. Neurochem. 20: 97-108.

Bartlett, W. P., and G. A. Banker (1984) An electron microscopic study of the development of axons and dendrites by hippocampal neurons in culture. J. Neurosci. 4: 1944-1953.

Behnke, O., and A. Forer (1967) Evidence for four classes of microtubules in individual cells. J. Cell Sci. 2; 169-192.

Black, M. M., and L. A. Greene (1982) Changes in the colchicine susceptibility of microtubules associated with neurite outgrowth: Studies with nerve growth factor responsive $\mathrm{PC} 12$ pheochromocytoma cells. J. Cell Biol. 95: 379-386.

Black, M. M., and P. Keyser (1986) Acetylation of $\alpha$-tubulin in cultured neurons (abstr.). J. Cell Biol. 103: 128a.

Black, M. M., and J. T. Kurdyla (1983a) Post-translational modification of tubulin in cultured neurons. Brain Res. 289: 355-357.

Black, M. M., and J. T. Kurdyla (1983b) Microtubule-associated proteins of neurons. J. Cell Biol. 97: 1020-1028.

Black, M. M., J. M. Cochran, and J. T. Kurdyla (1984) Solubility properties of neuronal tubulin: Evidence for labile and stable microtubules. Brain Res. 295: 255-263.

Black, M. M., P. Keyser, and E. Sobel (1986a) Interval between the synthesis and assembly of cytoskeletal proteins in cultured neurons. J. Neurosci. 6: 1004-1012.

Black, M. M., J. M. Aletta, and L. A. Greene (1986b) Regulation of microtubule composition and stability during nerve growth factor promoted neurite outgrowth. J. Cell Biol. 103: 545-557.

Bonner, W. M., and R. A. Laskey (1974) A film detection method for tritium-labeled proteins and nucleic acids in polyacrylamide gels. Eur. J. Biochem. 46: 83-88. 
Brown, B. A., R. A. Nixon, and C. A. Marotta (1982) Posttranslational processing of $\alpha$-tubulin during axonal transport in CNS axons. J. Cell Biol. 94: 159-164.

Cleveland, D. W., and K. F. Sullivan (1985) Molecular biology and genetics of tubulin. Annu. Rev. Biochem. 54: 331-365.

Drubin, D. G., S. C. Feinstein, E. M. Shooter, and M. W. Kirschner (1985) Nerve growth factor-induced neurite outgrowth in PC12 cells involves the coordinate induction of microtubule assembly and assembly-promoting factors. J. Cell Biol. 101: 1799-1807.

Eipper, B. A. (1972) Rat brain microtubule protein: Purification and determination of covalently bound phosphate and carbohydrate. Proc. Natl. Acad. Sci. USA 69: 2283-2287.

Estridge, M., and R. Bunge (1978) Compositional analysis of growing axons from rat sympathetic neurons. J. Cell Biol. 79: 138-155.

Farrell, K. W., and L. Wilson (1978) Microtubule reassembly in vitro of Strongylocentrotus purpuratus sperm tail outer doublet tubulin. J. Mol. Biol. 121: 393-410.

Field, D. J., and J. C. Lee (1985) Isoelectric focusing and two-dimensional electrophoresis of tubulin using immobilized $\mathrm{pH}$ gradients under denaturing conditions. Anal. Biochem. 144: 584-592.

Field, D. J., R. A. Collins, and J. C. Lee (1984) Heterogeneity of vertebrate brain tubulins. Proc. Natl. Acad. Sci. USA 81: 4041-4045.

Gard, D. L., and M. W. Kirschner (1985) A polymer-dependent increase in phosphorylation of $\beta$-tubulin accompanies differentiation of a mouse neuroblastoma cell line. J. Cell Biol. 100: 764-774.

Gozes, I., and K. J. Sweadner (1981) Multiple tubulin forms are expressed by a single neurone. Nature 294: 477-480.

Greer, K., H. Maruta, S. W. L'Hernault, and J. L. Rosenbaum (1986) $\alpha$-Tubulin actylase activity in isolated Chlamydomonas flagella. $\mathrm{J}$. Cell Biol. 102: 2081-2084.

Keen, J. H., and M. M. Black (1986) The phosphorylation of coated membrane proteins in intact neurons. J. Cell Biol. 102: 1325-1333.

LeDizet, M., and G. Piperno (1986) Cytoplasmic microtubules containing acetylated $\alpha$-tubulin in Chlamydomonas reinhardtii: Spatial arrangement and properties. J. Cell Biol. 103: 13-22.

L'Hernault, S. W., and J. L. Rosenbaum (1983) Chlamydomonas $\alpha$-tubulin is posttranslationally modified in the flagella during flagellar assembly. J. Cell Biol. 96: 258-263.
L'Hernault, S. W., and J. L. Rosenbaum (1985) Chlamydomonas $\alpha$-tubulin is posttranslationally modified by acetylation on the $\epsilon$-amino group of a lysine. Biochemistry $24: 473-478$.

Luca, F. C., and R. B. Vallee (1986) A monoclonal antibody that cross-reacts with phosphorylated epitopes on two microtubule-associated proteins and two neurofilament polypeptides. Proc. Natl. Acad. Sci. USA 83: 1006-1010.

Marotta, C. A., J. L. Harris, and J. M. Gilbert (1978) Characterization of multiple forms of brain tubulin subunits. J. Neurochem. 30:14311440.

Maruta, H., K. Greer, and J. L. Rosenbaum (1986) The acetylation of alpha-tubulin and its relationship to the assembly and disassembly of microtubules. J. Cell Biol. 103: 571-579.

Moura Neto, V., M. Mallat, C. Junket, and A. Prochaintz (1983) Microheterogeneity of tubulin proteins in neuronal and glial cell from the mouse brain in culture. EMBO J. 2: 1243-1248.

Peng, I., L. I. Binder, and M. M. Black (1985) Cultured neurons contain a variety of microtubule-associated proteins. Brain Res. 361: 200211.

Peng, I., L. I. Binder, and M. M. Black (1986) Biochemical and imInunological analyses of cytoskeletal domains of neurons. J. Cell Biol. 102: 252-262.

Piperno, G., and M. T. Fuller (1985) Monoclonal antibodies specific for an acetylated form of $\alpha$-tubulin recognize antigens in cilia and flagella from a variety of organisms. J. Cell Biol. 101: 2085-2094.

Raybin, D., and M. Flavin (1977) Modification of tubulin by tyrosylation in cells and extracts and its effects on assembly in vitro. J. Cell Biol. 73: 492-504.

Sale, W. S., J. C. Besharse, and G. Piperno (1986) Distribution of acetylated $\alpha$-tubulin in photoreceptors and neurons from amphibian retinas (abstr.). J. Cell Biol. 103: 128a.

Sullivan, K. F., and L. Wilson (1984) Developmental and biochemical analyses of chick brain tubulin. J. Neurochem. 42: 1363-1371.

Wold, F. (1981) In vivo chemical modification of proteins. Annu. Rev. Biochem. 50: 783-814. 